\title{
Consumer Credit as Lifestyle Interests Facilitators for Consumers
}

$$
\text { of Bangladesh }
$$

\author{
Ataur Rahman \\ Department of Business Administration \\ Southeast University, Banani, Dhaka-1213, Bangladesh \\ E-mail: ataurrahman74@yahoo.com
}

\begin{abstract}
Limited income people in Bangladesh are not solvent enough to buy essential household durables (like TV, fridge, furniture, sofa-set etc.) to enhance the lifestyle interests after fulfillment of their basic needs. They need consumer credit to buy these products for satisfying their lifestyle interests. The purpose of the study is to identify the consumer credit impacts on lifestyle interests of consumers of Bangladesh. 576 respondents in a survey were asked to rate the importance of 15 lifestyle interests variables related to consumer credit. These data were tested via factor analysis (the principal components method with varimax rotation) by using SPSS program. The results show that people borrow money to buy household goods to gratify their desired interests to family, home, recreation, fashion and food. The thesis will make contribution to our understanding that people need consumer credit to suit their desired interest to family, home, recreation, fashion, food etc.
\end{abstract}

Keywords: Consumer, Consumer credit, Lifestyle interests, Family, Home, Recreation, Fashion, Food

\section{Introduction}

Bangladesh is a developing country. A sizeable portion of population of this country is coming up as a consumer class every year. Because of huge population base, this class is quite large. Precisely, middle class and fixed income group belongs to this and they are in continuous race to elevate the standard of their living and quality of life. In doing so, it can not afford to possess basic necessities of life by paying the price at a time out of their savings (National Bank Bangladesh Ltd., 2006). Because of limited income, they have no ability to buy essential household durables (like TV, fridge, furniture, sofa-set etc.) to enhance the lifestyle interests after fulfillment of their basic needs. In this situation, credit is necessary for them to buy household goods. But their financial positions do not allow them to get micro credit; because micro credit is for poverty alleviation. They have no ability to get mortgage loan. To materialize their cherished goal of becoming the owners of the durable goods, at first Islami Bank Bangladesh Ltd. offered an attractive opportunity of installment buying through a consumer credit scheme named 'Household Durable Scheme' in 1993 in Bangladesh (Islami Bank Bangladesh Ltd, 1994). It was followed by Prime Bank Ltd. and Social Investment Bank Ltd., all of which started their services in 1995. Soon several other banks joined and today 19 of the 48 commercial banks offer consumer credit services (Bangladesh Bank, 2006).

The banking sector as a whole plays an important role in the economy of a country irrespective of its level of development. The commercial banks have greater responsibility both in the areas of product growth and in the performance of individual and social obligations. By lending consumer credit, commercial banks play an important role in individuals and society. By borrowing the loan, consumers can easily buy their household products. Using products, they can satisfy their desired interests to their family, home, recreation, fashion and food etc. The objective of the present study is to identify the consumer credit impacts on lifestyle interests of consumers of Bangladesh.

\section{Literature Review}

Consumer credit/ consumer credit institutions were first introduced at Chicago in 1878(Beckman \& Foster, 1969). These spread after World War II. After 1952, attitudes towards consumer credit changed dramatically. After 1968, sub-continental country began to introduce consumer credit (Suneja, 1994). At first Islami Bank Bangladesh Ltd. introduced consumer credit scheme in Bangladesh in 1993(Islami Bank Bangladesh Ltd., 1994).

Researchers have identified that consumer credit is for purchasing consumer goods and services(Stokes \& Artt ,1955), personal consumption (Prather, 1969), nonbusiness use (Garman \& Forgue, 1991), improving the standard of living (Suneja, 1994). So, consumer credits are loans granted by bank to individuals' for personal households or family consumption who may feel inclined to purchase consumer durables to improve the lifestyle.

Previous researchers have identified lifestyle as distinct mode of living( Lazer, 1963), way to allocate income(Zablocki and Kanter,1976), unified pattern of behavior(Berkman and Gilson, 1978), pattern of individual and social behavior 
(Veal,1989), pattern of living reflected by activities, interests and opinions (Kotler \& Armostrong, 2007). So, lifestyle can be defined as: Lifestyles are consumer pattern of living in the world as expressed in their activities, interests and opinions, pattern of consumption, spending time and money along with product, service and media.

Plummer (1974) measured people's lifestyle in terms of (i) how they spend their time, (ii) their interests, what they place importance on in their immediate surroundings, (iii) their opinions in terms of their view of themselves and the world around them, and (iv) Some basic characteristics such as their stage in lifecycle, income, education, and where they live. He listed the elements included in each major dimension of lifestyle. These elements are: activities-work, hobbies, social events, vacation, entertainment, club membership, community, shopping, sports; interests-family, home, job, community, recreation, fashion, food, media, achievements; opinions-themselves, social issues, politics, business, economics, education products, future, culture; demographics-age, education, income, occupation, family size, dwelling, geography, city size, stage in life cycle. Plummer concept helps marketer to find out the basic need of the consumer and how the products fit into their lives.

From the definition and measurement of lifestyle, and definition of consumer credit, it can be assumed that there may be a relationship between consumer credit and lifestyle interests. Following discussion will help to interpret the relationship between consumer credit and lifestyle interests.

Beckman \& Foster (1969) opined that the better music, drama and educational messages often heard over the radio or seen on TV are but one illustration of what has been made available through installment credit. People would deprive to get message from watching TV, if they have no opportunity to buy it by installment credit. He also added that it has aided people in securing higher standards of living, education, comforts, conveniences, efficiency, recreation and health.

People need consumer credit to buy household goods (like TV, computer etc.) to do their recreation: escaping, or being diverted from problems; relaxing; getting intrinsic cultural or aesthetic enjoyment; filling time; emotional release; sexual arousal (Chandler, 1994). TV, for example, is the most attractive and up-to-date means of recreation. It brings the scenes of different countries and people of the world before our eyes. It telecasts news, views, music, drama, films, national and international games and sports (Rob, 2008). People watch all programs on the TV screen just sitting in their drawing room. They sit before a TV set and enjoy football, cricket, tennis and other games (Rahman and Noor, 2008; Sarker \& Islam, 2008). Computer helps people to play different kind of games (like chess, fighting, car racing etc.). It also helps to enjoy cultural programs. It can store music, drama, dance, sports program etc. People enjoy these programs in their convenience time (Mohiuddin and Kashem, 2008).

Amling \& Droms (1982) identified the association between consumer credit and peoples' interest to solve the necessity of their personal or family needs. They are responsible for many of their occasions: birth, death, sickness and similar events, which demand a large immediate outlay. Very often credit is necessary to solve these emergency conditions. People need credit to buy household goods (like TV, fridge, furniture etc.) to get affiliation of family solidarity; family relaxant; conflict reduction and relationship maintenance (Lull, 1990).

People need consumer credit to buy TV/computer for satisfying their desired interests to fashion. Kaiser and Chandler (1985), for example, observed that older people implicitly use television for processing appearance and fashion-related information. Surprisingly, the mature market represents the second fastest growing population segment engaged in internet use. Therefore, the internet may also become a viable source of fashion information (Bernthal et al., 2005).

Assael (1998) described that the focus on time savings convenience in the 1990s has created two trends in interests to food consumption: (i) Grazing- It is the need to eat on the run. People eat breakfast in the car on the way to work, munch on a sandwich while walking, or eat lunch at their desks. (ii) Refueling refers to less time spent in preparing and eating dinner. The primary reflection of this trend is the growing importance of household goods (like microwave ovens, fridge, pressure cooker, blender etc.) in people's lives for preparing food and keeping food in store. People need consumer credit to buy these products to satisfy their interests to food.

Well decoration of a home is very much necessary to stay there for a long time. An ideal home is the abode of peace, love, and affection. It is associated with all that is sweet, pleasant and agreeable in life (Mohiuddind and Kashem, 2008). People need credit to buy furniture and others household goods for decorating their home.

Previous researchers' discussion indicated that people need consumer credit to buy household goods for satisfying their interests to family, home, recreation, fashion, food etc. It is clear that they showed clue about the association between consumer credit and peoples' lifestyle interests to family, home, recreation, fashion, food etc. But no research has been done to investigate the relationship between consumer credit and lifestyle interests of consumers of Bangladesh. This thesis seeks to make a substantial contribution in this area. Thus, this paper seeks to answer a research question. How does consumer credit help to satisfy the desired interests to family, home, recreation, fashion and food of consumers of Bangladesh? 


\section{Conceptual Frame Work \& Development of Hypothesis}

Based on the findings of the existed study, the major factors which may influence to borrow consumer credit to satisfy their lifestyle interests can be classified into family, home, recreation, fashion and food. A conceptual model of consumer credit impacts on lifestyle interests of consumers has then been derived and presented in appendix (figure 1).The model is a comprehensive one and should be capable of capturing the relevant factors underlying the problem. A number of variables have been included to measure consumer credit impact on the lifestyle interests of consumers of Bangladesh. The variables are involved under categories of lifestyle interests' factors. These are family, home, recreation, fashion and food

People need credit to buy products for their family members. A car, for example, gives them the convenience they seek while protecting their family (Arab Bangladesh Bank, 2005). TV, fridge, and sofa set all of the household goods are very much necessary for family members. They buy household goods (TV, fridge, bed, almira, sofa set, dinning table etc.) for decorating their home. People need household goods for recreation. People enjoy cinema, drama, and such other popular programs by watching TV and listening to radio. People who are interested to fashion want to buy different kind of fashion goods. Swing machine, furniture, sofa set, almira etc. are fashion goods. These goods help to maintain their fashion. They need fridge for fresh food, vegetables and drinks. They can maintain balanced diet by using fridge. Blender machine is necessary for juice, pressure cooker is necessary for quick food \& oven is necessary for warming food.

From the above discussion, it can be said that people are interested to particular factors like family, home, recreation, fashion and food etc. They need credit to buy household goods for their interest of those factors. So it can be assumed that there may be an association between consumer credit \& people's lifestyle interests. Hypotheses $(\mathrm{H})$ as formulated in this section along with the expected effect on the consumer credit impacts on lifestyle interests are summarized as follows:

H1. There is a strong association between consumer credit and people's lifestyle interests.

As lifestyle interests includes family, home, recreation, fashion and food; therefore, for the purpose of the study, it can develop the following five sub-hypotheses.

H1a. There is a strong association between consumer credit and people's interests to family.

$\mathrm{H} 1 \mathrm{~b}$. There is a strong association between consumer credit and people's interests to home.

H1c. There is a strong association between consumer credit and people's interests to recreation.

H1d. There is a strong association between consumer credit and people's interests to fashion.

H1e. There is a strong association between consumer credit and people's interests to food.

\section{Research Methods}

The strategy adopted for this study is the personal interview survey. Considering the nature of the present study, a combination of structured and unstructured interview schedules was used in order to explore both quantitative and qualitative information. Six set of questionnaires were used to collect information. Dhaka-the capital city of Bangladesh was chosen as study area for this study. Addresses \& phone number of borrowers (respondents) were collected from office file of the sample branches by the employees of the banks for interview. Sample size determination formula is used for identifying total number of sample.

Sample size determination method:

$\mathrm{N}=\left\{\mathrm{p}(1-\mathrm{p}) \mathrm{z}^{2} / \mathrm{d}^{2}\right\} * \mathrm{deft}$

$\mathrm{N}=$ size of the sample

$\mathrm{P}=$ the proportion to be estimated $=0.5$

$\mathrm{Z}=$ value of standard normal variate $=95 \%$ level of significance $=1.96$

$\mathrm{D}=$ the amount of tolerated margin of error $=0.05$

Deft $=$ design effect $=1.5$

Number of sample $=\left[\left\{0.5(1-0.5)(1.96)^{2}\right\} /(0.05)^{2}\right]^{*} 1.5=576$

576 borrowers were selected as sample for interviewing. At first target population is divided into mutually exclusive and collectively exhaustive subpopulation or cluster. That means 301 clusters (branch as cluster). Random sample of cluster (branch as cluster) is selected based on probability sampling technique. Here, 30(branches as cluster) cluster are selected as sample by using probability proportionate to size sampling method from 301 branches. All borrowers in each selected branch (cluster) are not possible to include in the sample because of time and cost constraints. For this reason, probability proportionate to size sampling of two stage cluster sampling method is used for selecting number of 
borrowers from each branches. Each borrower is selected by using systematic manners of simple random sampling method.

Data were collected on relevant variables from primary and secondary sources. Primary sources included borrowers who bought household goods by consumer credit from the banks. Secondary data have been collected from journals, books, the published contents of the annual reports, relevant brochures, sales figures, and prior research reports of the listed banks internal sources and suppliers.

\section{Data Analysis}

For the analyses, cases with incomplete profiles were deleted. Further, responses to individual items of "Refused" were recorded as missing data. The statistical program, SPSS for Windows (SPSS, 2004), was used for all analyses. For identifying consumer credit impacts on lifestyle interests, respondents in a survey were asked to indicate their degree of agreement with 15 statements/ variables (appendix, table 7) using a 5-point likert scale ( $1=$ strongly disagree, $5=$ strongly agree).These data were analyzed via principal components analysis. The factor analysis using the principal components method with varimax rotation was run to determine the underlying benefits consumers seek of their lifestyle interests(family, home, recreation, fashion, food) from the using of household goods (TV, fridge, furniture etc.) borrowed by consumer credit.

The correlation matrix, constructed from the data obtained to understand lifestyle interest is shown in appendix (appendix, table 1). There are relatively high correlations among V1, v15; As like as, v2, v3, v13; Likely, v4, v6, v8; Similarly, v5, v7, v9, v10, v11; As like as, v12, v14. So above variables are correlated with each other. These variables may also be expected to correlate with the same factors. In appendix (table 2), it is seen that the approximate chi-square statistic is 674.072 with $105\{0.5 \mathrm{p}(\mathrm{p}-1)$ where, $\mathrm{p}=$ number of variables $\}$ degrees of freedom, which is significant at the 0.05 level. The value of the KMO statistic $(0.760)$ is also large $(>0.5)$. Thus, factor analysis may be considered as an appropriate technique for analyzing the correlation matrix (appendix, table 1).

Priori determination, and approaches based on eigenvalues, scree plot, percentages of variance accounted are applied to identify the numbers of factors. Five factors are extracted from lifestyle interests' variables by priori determination method. Under "Communalities", "initial column", it can be seen that the communality for each variable, v1 to v15, is 1.0 as unities are inserted in the diagonal of the correlation matrix (appendix, table 3 ). In appendix, table 4, it is seen that the eigenvalue greater than 1.0 (default option) results in five factors extracted. The priori knowledge tells researcher that household product is bought for five major interests of people. The scree plot associated with this analysis is given in appendix (figure 2). From the scree plot, a distinct break occurs at five factors. Finally, from the cumulative percentages of variance accounted for, it is seen that the first five factors account for 76.52 percent of the variance, and that the gain achieved in going to five factors is marginal(appendix, table 4). Thus, five factors appear to be reasonable in this situation.

The rotated factor (component) matrix contains the coefficients used to express the standardized variables in terms of the factors (appendix, table 5). In the rotated factor matrix of appendix(table 5), factor 1 has high coefficients for variables V5 (Borrowed consumer credit to purchase household goods helps to get affiliation of family solidarity, relaxation and relationship), v7 (Borrowed consumer credit to purchase household goods helps to exhibit family status), V9 (Borrowed consumer credit to purchase sofa set helps family members to comfort sitting on sofa set), V10 (Borrowed consumer credit to purchase dinning table helps family members to make comfort sitting and eating on dinning table), V11 (Borrowed consumer credit to purchase khat(bed) helps family members to comfort sleeping on khat etc. variables). Therefore, this factor may be labeled as family interest factor.

Likewise, there are relatively high correlations among V2 (Borrowed consumer credit to purchase TV helps to stay at home for leisure time and entertainment, thereby avoiding issues such as pollution), V3 (Borrowed consumer credit to purchase household goods helps to perform household task), V13 (Borrowed consumer credit to purchase TV/ computer/ car/ motorcycle helps to collect lots of information about home). Thus factor 2 may be labeled as home interest factor.

Similarly, V4 (Borrowed consumer credit to purchase car/ motorcycle helps to maintain community), V6 (Borrowed consumer credit to purchase car/ motorcycle helps the family members to visit enjoyable place for recreation), v8 (Borrowed consumer credit to purchase TV helps to reduce emotion, worries, problem, tiredness etc.). These factors may be leveled as recreation interest factor.

Likely, v1 (Borrowed consumer credit to purchase fridge helps to keep food, fruits, and vegetables etc. fresh), v15 (Borrowed consumer credit to purchase fridge, oven, toaster machine, blender etc. helps to enjoy fast food, juice \& other tasty food). So, factor 4 may be labeled as food interest factor.

Remaining, v12 (Borrowed consumer credit to purchase TV helps to find out latest fashion), v14 (Borrowed consumer credit to purchase household goods helps to decorate the home in new style) indicate factor-5, may be fashion interest factor. 
From the analysis, it can be said that consumers appear to seek five major kinds' of interest (family, home, recreation, fashion, and food) from household goods bought by consumer credit. The model is very much fit because of less number of residual (appendix, table 6). So, it is justified that there is a strong association between consumer credit \& people's lifestyle interests.

\section{Findings}

The findings of the study summarized in appendix (table 7) show that people borrow consumer credit to buy household goods for the interest of their family, home, recreation, food and fashion. Factors loading of variables and $\%$ of variance of the factors shown in appendix (table 7) prove the hypothesis that there is a strong association between consumer credit and people's lifestyle interests. The following is a brief discussion of each factor in the order of its contribution to the total variance.

Factor-1: Family. This factor contains five variables, two of which have relevance to get affiliation of family solidarity, relaxation, relationship, and exhibiting family status; and the other three to get comfort sitting, eating and sleeping. The examination of consumer credit impacts on lifestyle interests reveals that all seven variables were highly significant (table 7).People need credit to buy household goods (TV, fridge, computer etc.) for satisfying their desired interests to get affiliation of family solidarity, relaxation and relationship. Household goods help them to show their family status. The status is seen more through ownership of status products than through personal, occupational, or family reputation (Eastman et al., 1997). Sofa set, for example, is very much necessary for family members to maintain guest \& to show their status to the society. A dinning table is necessary for family members comfort eating on sitting. It is also necessary for a family to maintain guest $\&$ to show their status to the society. Bed (Khat) is very much necessary for a family to comfort lying, maintain guest $\&$ to show their status to the society. It is also helpful for passing leisure time by watching $\mathrm{TV}$, reading book \& gossip with family members.

Factor-2: Home. In the present analysis, this factor explained the second highest variance (table 7).Of the three variables, one was indicated to stay at home for leisure time and entertainment, another was to perform household task and next one was indicted to collect information about home. All three variables were highly significant (table 7). People need consumer credit to buy household goods for decorating their home. Well decoration of a home is very much necessary to stay there in long time. TV/ computer/ VCP etc. help them to enjoy cinema, drama, and such other popular programs without going to outside of the home (Mohiuddin \& Kashem, 2008). People want to stay at home not only for leisure time but also for household task. Household goods help them to perform household tasks. Pressure cooker, for example, helps quick cooking. Blender helps to make juice, oven helps to warm food. Computer helps to store \& disseminate information. It helps to calculate transactions etc. People collect lots of information about decorating the home by watching television and using computer.

Factor-3: Recreation. In the present analysis, this factor explained the third highest variance (appendix, table 7).Of the three variables, one was indicated to maintain community, another was to visit enjoyable place and next one was to reduce emotion, worries, problems and tiredness. All three variables were highly significant (appendix, table 7). Borrowed money to buy household goods helps people to do recreation. People can attend any community activities very easily if they have a car. A car is a prestigious product with very much relation to maintain community. The people who are very much interested to visit enjoyable place for recreation, they need a car. Some people want outdoor recreation. They want to go to park, museum, zoo, restaurant, lake and other enjoyable places. By watching TV programmes (like dance, song, drama), a person can reduce his emotion, worries, problem, and tiredness. Comfort sitting on sofa set also reduces people's tiredness.

Factor-4: Food. This factor contains two variables, one of which has relevance to enjoy food; the other is to keep food fresh. The examination of consumer credit impacts on lifestyle interests reveals that all two variables were highly significant (table 7).People borrow money to buy household goods(fridge, blender, oven etc.) to satisfy their desired interests to food. Consumer who is very much interested to eat varieties of food, they need food preparation materials. They make juice with the help of blender machine. They warm food with the help of oven. They make fast food with the help of toaster machine. People are now very busy. They need to eat on the run. They need to eat breakfast in the car on the way to work, munch on a sandwich while walking, or eat lunch at their desks. They need to take less time spent in preparing and eating food. Fridge, pressure cooker, blender and microwave ovens are very much necessary for solving these problems. People make bread and fry eggs in idle time. They buy food, fruits, and vegetables in holiday or idle time. They keep these into fridge. They make warm these by microwave ovens and consume it into busy time. In this way, people can activate their work by maintaining good health.

Factor-5: Fashion. This factor contains two variables, one of which has relevance to find out latest fashion, the other is to decorate the home in a new style. The investigation of consumer credit impacts on lifestyle interests reveals that all two variables were highly significant (table 7).People borrow money to buy household goods to satisfy their desired interests to fashion. People collect lot of information about fashion by watching television, using computer. Most of the consumers gather knowledge about the fashion from TV advertisement. They are also learning about the fashion from 
film. They mainly follow the fashion of reference group (secondary) like film star, hero, heroin, sportsman, singer by watching TV. People want to decorate their house in a new style. House can be decorated by household goods like TV, fridge, sofa set, almirah, showcase etc.

From the discussion, it is clear that consumer credits have great impact on lifestyle interests' factors. People need credit to buy household goods mainly for satisfying their lifestyle interests to family, home, recreation, fashion, food.

\section{7: Implication \& Conclusion of the Study}

The study establishes the relevance of consumer credit influence on consumer lifestyle interests. This implies that managers of banks are likely to benefit considerably in targeting and positioning and their media communication by focusing their attention on the ongoing changes in lifestyle interests of their consumers by using household goods borrowed by consumer credit.

People need consumer credit to buy household goods (TV, fridge etc.) for satisfying their desired interest to family, home, recreation, fashion and food. Furniture, TV, fridge, khat, almirah, dinning table, sofa set is very much necessary for well decorated home. Fridge, blender machine, micro oven are necessary for fresh and available food and also balanced diet. TV, computer etc. help to fulfill the recreation interest of the people circulated by different program in different channels. Households' goods show social status of the family. These help people to differentiate them from other members of the society. They learn fashion from watching TV. The findings of the thesis will be very much helpful for managers to make understand the consumer by communicating that using household goods borrowed by consumer credit helps people to satisfy their desired interest (to family, home, recreation, fashion \& food) .

From the analysis of this thesis; it is proved that there is a strong relationship between consumer credit and people's lifestyle interests. So people borrow money to purchase household goods for satisfying their lifestyle interests. In a consumption environment, a person chooses a product or brand, which seems to possess a maximum possibility of the definition or elaboration of his lifestyle interests. This thesis will help manager to understand the individual's consumer credit consumption behavior by analyzing the details of his lifestyle interest system, which will help them to take marketing strategy to expand the consumer credit scheme. Consequently, this thesis showing that there is a causal effect of the individual's lifestyle interests on his consumer credit consumption behavior. This thesis will help manager to make different strategy for overcoming the limitation of existing consumer credit scheme in different banks of Bangladesh. They can make different strategy for improving the consumer credit scheme so that it can be satisfied the desired interests of people.

\section{References}

Amling, F. and Droms, G.W. (1982). Personal Financial Management. Homewood, IL: Irwin Professional Publishing.

Arab Bangladesh Bank Limited. (2005). Brochure of Arab Bangladesh Bank Limited. Dhaka: Public Relations Department, Arab Bangladesh Bank Limited.

Assael, H. (1998). Consumer Behavior and Marketing Action. Cincination, OH: South-Western Publication.

Bangladesh Bank. (2006). Scheduled Banks Statistics. Quarterly (October-December).Dhaka: Statistics Department, Bangladesh Bank.

Beckman, T.N. and Foster. (1969). Credit and Collections. New York: Mcgraw-Hill Book Company.

Berkman, H.W. and Gilson, C.C. (1978). Consumer Behavior. Boston: Kent Publishing Company.

Bernthal, M. J.; Crockett, D. and Rose, R. L. (2005). Credit Cards as Lifestyle Facilitators. Journal of Consumer Research, 32 (June), 129-145.

Chandler, D.(1994). Why do people watch television. UWA.

Eastman, J.K.; Bill, F., David, C. and Stephen, C. (winter, 1997). The Relationship between Status Consumption and Materialism: A Cross-Cultural Comparison of Chinese, Mexican, and American Students. Journal of Marketing Theory and Practice, 52-66.

Garman, E. T. and Forgue, R. E. (1991). Personal Finance. Third Edition. Boston: Houghton Mifflin Company.

Islami Bank Bangladesh Limited. (1994). Brochure of Islami Bank Bangladesh Limited. Dhaka: Public Relations Department, Islami Bank Bangladesh Limited.

Kaiser, S.B. \& Chandler, J.L. (1985). Older Consumers' Use of Media for Fashion Information. Journal of Broadcasting and Electronic Media, 29, 201-207.

Kotler, P. and Armostrong, G. (2007). Principles of Marketing. New Delhi: Prentice -Hall of India Private Ltd.

Lazer, W. (1963). Lifestyle Concepts and Marketing. In Toward Scientific Marketing, Ed. Stephen A. Greyser (Chicago: American Marketing Association). 
Lull J. (1990). Family Communication Patterns and the Social Uses of Television. In Inside Family Viewing: Ethnographic Research on Television's Audiences. London: Routledge, pp. 49-61

Mohiuddin, A.H.M. and Kashem, A.F.M.A. (2008). Advanced Functional English. $\quad$ Dhaka: Ideal Library.

National Bank. (2006). Brochure of National Bank Ltd. Dhaka: Public Relation Department of National Bank

Plummer, T.J. (1974). The Concept and Application of Life Style Segmentation. The Journal of Marketing, 38, 33-37.

Prather, C.J. (1969). Money and Banking. Irwin, Proceedings of the National Consumer Credit Conference for 1951, Lehigh University, 1951.

Rahman M. \& Noor M.S. (2008). Communicating English Grammer with Composition. Grammer Bitan Publication, 38, Banglabazar Dhaka-1100.

Rob, F.M.A. (2008). Self Teaching English Language, Grammar, Translation \& Composition. Hassan Book Depot, 38, Banglabazar, Dhaka.

Sarker, R.K. \& Islam, M.N. (2008). Discovery Communicated English Grammar \& Composition. Hassan Book Depot, Mehar Plaza (19 Th Fllor), 33. Topkhana Road, Dhaka.

SPSS. (2004). Statistical Package for the Social Science: 12.0. SPSS Inc. Chicago, IL.

Stokes, L.M. and Arlt, T.C. (1955). Money, Banking and Financial System. New York: Ronald Press.

Suneja, H.R. (1994). Innovation in Banking Services. Annual Report in the Trend and Progress of Banking in India. R. B. I., 7.

Veal, A.J. (1989). Leisure, Lifestyle and Status: A Pluralistic Framework for Analysis. Leisure Studies, 8 (2), 141-54.

Zablocki, B.D. and Kanter, R.M. (1976).The Differentiation of Lifestyles. Annual Review of Sociology, 269-97.

\section{Appendix}

Table 1. Correlation(C) Matrix about some lifestyle (interests) variables related to consumer credit.

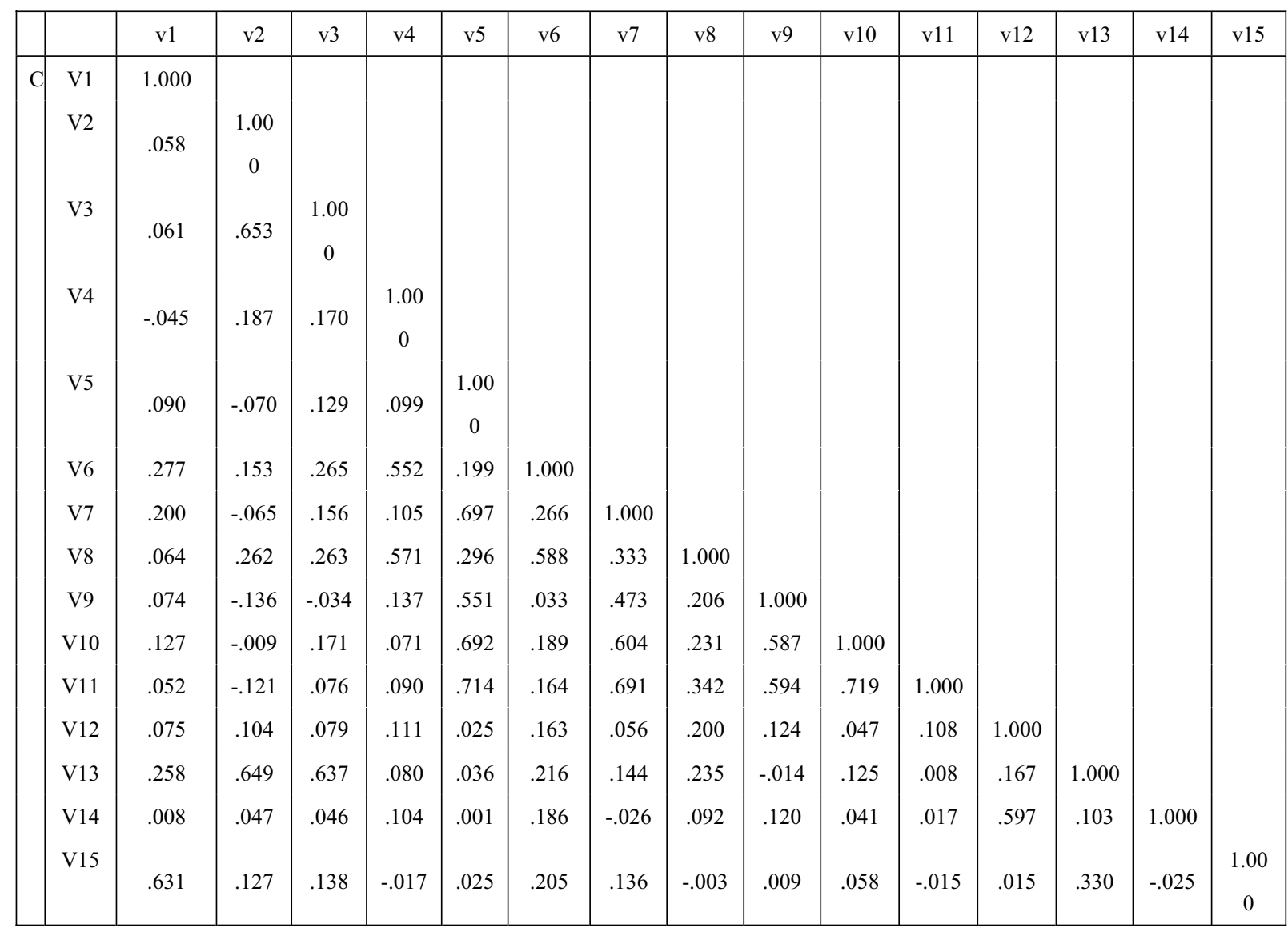


Table 2. KMO and Bartlett's Test of Sphericity of some lifestyle (interests) variables related to consumer credit.

\begin{tabular}{|c|c|c|}
\hline \multicolumn{2}{|c|}{$\begin{array}{l}\text { Kaiser-Meyer-Olkin Measure of Sampling } \\
\text { Adequacy. }\end{array}$} & .760 \\
\hline Bartlett's Test of & Approx. Chi-Square & 674.072 \\
\hline Sphericity & df & 105 \\
\hline & Sig. & .000 \\
\hline
\end{tabular}

Table 3. Communalities of some lifestyle (interests) variables related to consumer credit.

\begin{tabular}{|l|r|r|}
\hline & \multicolumn{1}{|c|}{ Initial } & Extraction \\
\hline v1 & 1.000 & .816 \\
\hline v2 & 1.000 & .802 \\
\hline v3 & 1.000 & .782 \\
\hline v4 5 1 & 1.000 & .757 \\
\hline v6 & 1.000 & .767 \\
\hline v7 & 1.000 & .770 \\
\hline v8 & 1.000 & .712 \\
\hline v9 & 1.000 & .744 \\
\hline v10 & 1.000 & .600 \\
\hline v11 & 1.000 & .748 \\
\hline v12 & 1.000 & .803 \\
\hline v13 & 1.000 & .788 \\
\hline v14 & 1.000 & .795 \\
\hline v15 & 1.000 & .801 \\
\hline
\end{tabular}

Extraction Method: Principal Component Analysis.

Table 4. Total Variance Explained of some lifestyle (interests) variables related to consumer credit.

\begin{tabular}{|c|c|c|c|c|c|c|c|c|c|}
\hline \multirow[t]{2}{*}{ Component } & \multicolumn{3}{|c|}{ Initial Eigenvalues } & \multicolumn{3}{|c|}{$\begin{array}{c}\text { Extraction Sums of Squared } \\
\text { Loadings }\end{array}$} & \multicolumn{3}{|c|}{ Rotation Sums of Squared Loadings } \\
\hline & Total & $\begin{array}{c}\% \text { of } \\
\text { Variance }\end{array}$ & $\begin{array}{c}\text { Cumulative } \\
\%\end{array}$ & Total & $\begin{array}{c}\% \text { of } \\
\text { Variance }\end{array}$ & $\begin{array}{c}\text { Cumulative } \\
\%\end{array}$ & Total & $\begin{array}{c}\% \text { of } \\
\text { Variance }\end{array}$ & $\begin{array}{c}\text { Cumulative } \\
\% \\
\end{array}$ \\
\hline 1 & 4.084 & 27.225 & 27.225 & 4.084 & 27.225 & 27.225 & 3.613 & 24.084 & 24.084 \\
\hline 2 & 2.736 & 18.239 & 45.464 & 2.736 & 18.239 & 45.464 & 2.334 & 15.563 & 39.647 \\
\hline 3 & 1.768 & 11.785 & 57.248 & 1.768 & 11.785 & 57.248 & 2.128 & 14.185 & 53.832 \\
\hline 4 & 1.503 & 10.019 & 67.268 & 1.503 & 10.019 & 67.268 & 1.774 & 11.827 & 65.659 \\
\hline 5 & 1.388 & 9.254 & 76.522 & 1.388 & 9.254 & 76.522 & 1.629 & 10.863 & 76.522 \\
\hline 6 & .611 & 4.073 & 80.594 & & & & & & \\
\hline 7 & .505 & 3.366 & 83.961 & & & & & & \\
\hline 8 & .396 & 2.641 & 86.602 & & & & & & \\
\hline 9 & .357 & 2.378 & 88.980 & & & & & & \\
\hline 10 & .330 & 2.203 & 91.183 & & & & & & \\
\hline 11 & .321 & 2.140 & 93.323 & & & & & & \\
\hline 12 & .299 & 1.995 & 95.318 & & & & & & \\
\hline 13 & .262 & 1.745 & 97.063 & & & & & & \\
\hline 14 & .235 & 1.566 & 98.630 & & & & & & \\
\hline 15 & .206 & 1.370 & 100.000 & & & & & & \\
\hline
\end{tabular}

Extraction Method: Principal Component Analysis. 
Table 5. Rotated Component Matrix of some lifestyle (interests) variables related to consumer credit (a)

\begin{tabular}{|l|l|l|l|l|l|}
\hline \multirow{2}{*}{} & \multicolumn{5}{|c|}{ Component } \\
\cline { 2 - 6 } & 1 & 2 & 3 & 4 & 5 \\
\hline v1 & .090 & .035 & .051 & .896 & .037 \\
\hline v2 & -.131 & .875 & .137 & -.011 & .030 \\
\hline v3 & .103 & .866 & .145 & .006 & -.009 \\
\hline v4 & .018 & .055 & .861 & -.105 & .040 \\
\hline v5 & .867 & .021 & .110 & .011 & -.047 \\
\hline v6 & .106 & .106 & .809 & .283 & .108 \\
\hline v7 & .807 & .055 & .160 &. .170 & -.056 \\
\hline v8 & .270 & .206 & .789 & -.041 & .073 \\
\hline v9 & .749 & -.112 & .023 & -.015 & .163 \\
\hline v10 & .857 & .105 & .033 & .046 & .012 \\
\hline v11 & .888 & -.031 & .107 & -.038 & .028 \\
\hline v12 & .059 & .084 & .095 & .031 & .876 \\
\hline v13 & .047 & .839 & .047 & .274 & .113 \\
\hline v14 & .005 & .019 & .074 & -.017 & .891 \\
\hline v15 & .007 & .148 & .004 & .877 & -.029 \\
\hline
\end{tabular}

Extraction Method: Principal Component Analysis. Rotation Method: Varimax with Kaiser Normalization.

a Rotation converged in 5 iterations.

Table 6. Reproduced Correlations (RC) of some lifestyle (interest) variables related to consumer credit.

\begin{tabular}{|c|c|c|c|c|c|c|c|c|c|c|c|c|c|c|c|c|}
\hline & & v1 & v2 & v3 & v4 & v5 & v6 & v7 & $\mathrm{v} 8$ & v9 & v10 & v11 & $\mathrm{v} 12$ & $\mathrm{v} 13$ & v14 & v15 \\
\hline \multirow[t]{15}{*}{$\mathrm{RC}$} & $\mathrm{v} 1$ & $.816(\mathrm{~b})$ & .017 & .052 & -.045 & .093 & .312 & .233 & .038 & .057 & .124 & .051 & .074 & .286 & .023 & .791 \\
\hline & v2 & .017 & .802 (b) & .764 & .167 & -.081 & .190 & -.039 & .256 & -.188 & -.016 & -.127 & .104 & .734 & .053 & 118 \\
\hline & v3 & .052 & .764 & $.782(b)$ & .174 & .124 & .221 & .156 & .320 & -.018 & .183 & .080 & .085 & .739 & .019 & .135 \\
\hline & v4 & -.045 & .167 & .174 & $.757(b)$ & .108 & .679 & .135 & .702 & .036 & .045 & .111 & .119 & .063 & .102 & -.082 \\
\hline & v5 & .093 & -.081 & .124 & .108 & $\begin{array}{r}.767( \\
\text { b) }\end{array}$ & .181 & .723 & .321 & .642 & .748 & .779 & .022 & .061 & -.030 & .021 \\
\hline & v6 & .312 & .190 & .221 & 679 & .181 & $\begin{array}{r}.770( \\
\text { b) }\end{array}$ & .263 & .685 & .100 & .143 & .170 & .196 & .222 & .154 & .265 \\
\hline & v7 & .233 & -.039 & .156 & .135 & .723 & .263 & $\begin{array}{r}.712( \\
\mathrm{b})\end{array}$ & .344 & .590 & .710 & .724 & .024 & .132 & -.036 & .165 \\
\hline & v8 & .038 & .256 & .320 & .702 & .321 & .685 & .344 & $\begin{array}{r}.744( \\
\text { b) }\end{array}$ & .210 & .278 & .321 & .171 & .219 & .129 & -.003 \\
\hline & v9 & .057 & -.188 & -.018 & .036 & .642 & .100 & .590 & .210 & $\begin{array}{r}.600( \\
\mathrm{b})\end{array}$ & .632 & .676 & .179 & -.044 & .148 & -.029 \\
\hline & v10 & .124 & -.016 & .183 & .045 & .748 & .143 & .710 & .278 & .632 & $\begin{array}{r}.748( \\
\text { b) }\end{array}$ & .759 & .075 & .143 & .018 & .062 \\
\hline & v11 & .051 & -.127 & .080 & .111 & .779 & .170 & .724 & .321 & .676 & .759 & $.803(b)$ & .083 & .013 & .037 & -.032 \\
\hline & v12 & .074 & .104 & .085 & .119 & .022 & .196 & .024 & . 171 & .179 & .075 & .083 & $\begin{array}{r}.788( \\
\text { b) }\end{array}$ & .185 & .789 & .016 \\
\hline & v13 & .286 & .734 & .739 & .063 & .061 & .222 & .132 & .219 & -.044 & .143 & .013 & .185 & $\begin{array}{r}.795( \\
\text { b) }\end{array}$ & .116 & .362 \\
\hline & v14 & .023 & .053 & .019 & .102 & -.030 & .154 & -.036 & .129 & .148 & .018 & .037 & .789 & .116 & $\begin{array}{r}.801(\mathrm{~b} \\
)\end{array}$ & -.037 \\
\hline & v15 & .791 & .118 & .135 & -.082 & .021 & .265 & .165 & -.003 & -.029 & .062 & -.032 & .016 & .362 & -.037 & $.792(b)$ \\
\hline \multirow[t]{15}{*}{ Residual(a) } & $\mathrm{v} 1$ & & .041 & .009 & .000 & -.003 & -.036 & -.033 & .027 & .017 & .002 & .001 & .001 & -.028 & -.015 & -.160 \\
\hline & v2 & .041 & & -.111 & .020 & .011 & -.037 & -.026 & .005 & .052 & .007 & .007 & .000 & -.085 & -.006 & .008 \\
\hline & v3 & .009 & -.111 & & -.004 & .005 & .044 & .000 & -.057 & -.016 & -.013 & -.004 & -.006 & -.102 & .027 & .004 \\
\hline & $\mathrm{v} 4$ & .000 & .020 & -.004 & & -.010 & -.127 & -.030 & -.132 & .101 & .026 & -.021 & -.008 & .016 & .002 & .065 \\
\hline & v5 & -.003 & .011 & .005 & -.010 & & .017 & -.027 & -.025 & -.090 & -.056 & -.065 & .002 & -.025 & .031 & .004 \\
\hline & v6 & -.036 & -.037 & .044 & -.127 & .017 & & .003 & -.098 & -.067 & .046 & -.006 & -.033 & -.005 & .033 & -.060 \\
\hline & v7 & -.033 & -.026 & .000 & -.030 & -.027 & .003 & & -.011 & -.117 & -.106 & -.033 & .032 & .012 & .011 & -.030 \\
\hline & v8 & .027 & .005 & -.057 & -.132 & -.025 & -.098 & -.011 & & -.004 & -.046 & .021 & .029 & .016 & -.037 & .000 \\
\hline & v9 & .017 & .052 & -.016 & .101 & -.090 & -.067 & -.117 & -.004 & & -.045 & -.082 & -.055 & .030 & -.029 & .038 \\
\hline & v10 & .002 & .007 & -.013 & .026 & -.056 & .046 & -.106 & -.046 & -.045 & & -.041 & -.027 & -.018 & .022 & -.003 \\
\hline & v11 & .001 & .007 & -.004 & -.021 & -.065 & -.006 & -.033 & .021 & -.082 & -.041 & & .025 & -.006 & -.020 & .017 \\
\hline & v12 & .001 & .000 & -.006 & -.008 & .002 & -.033 & .032 & .029 & -.055 & -.027 & .025 & & -.019 & -.193 & .000 \\
\hline & v13 & -.028 & -.085 & -.102 & .016 & -.025 & -.005 & .012 & .016 & .030 & -.018 & -.006 & -.019 & & -.013 & -.031 \\
\hline & v14 & -.015 & -.006 & .027 & .002 & .031 & .033 & .011 & -.037 & -.029 & .022 & -.020 & -.193 & -.013 & & .012 \\
\hline & v15 & -.160 & .008 & .004 & .065 & .004 & -.060 & -.030 & .000 & .038 & -.003 & .017 & .000 & -.031 & .012 & \\
\hline
\end{tabular}

Extraction Method: Principal Component Analysis.

a Residuals are computed between observed and reproduced correlations. There are $21(20.0 \%)$ nonredundant residuals with absolute values greater than 0.05 .

b Reproduced communalities 
Table 7. Some lifestyle (interests) variables, eigenvalue, factor loading of variables and \% of variance of factors related to consumer credit.

\begin{tabular}{|c|c|c|c|c|}
\hline $\begin{array}{l}\text { Brief } \\
\text { name of } \\
\text { Factors }\end{array}$ & $\begin{array}{l}\text { Factors } \\
\text { interpretation } \\
\text { (\% of variance } \\
\text { explained) }\end{array}$ & $\begin{array}{l}\text { Eigen } \\
\text { value }\end{array}$ & $\begin{array}{l}\text { Factors } \\
\text { loading }\end{array}$ & Name of Variables \\
\hline \multirow[t]{5}{*}{ F1 } & \multirow[t]{5}{*}{$\begin{array}{l}\text { Family } \\
(27.23)\end{array}$} & \multirow[t]{5}{*}{4.08} & .867 & $\begin{array}{l}\text { V5: Borrowed consumer credit to purchase household goods helps to get } \\
\text { affiliation of family solidarity, relaxation and relationship. }\end{array}$ \\
\hline & & & .807 & $\begin{array}{l}\text { V7: Borrowed consumer credit to purchase household goods helps to exhibit } \\
\text { family status. }\end{array}$ \\
\hline & & & .749 & $\begin{array}{l}\text { V9: Borrowed consumer credit to purchase sofa set helps family members to } \\
\text { comfort sitting on sofa set. }\end{array}$ \\
\hline & & & .857 & $\begin{array}{l}\text { V10: Borrowed consumer credit to purchase dinning table helps family } \\
\text { members to comfort sitting and eating on dinning table. }\end{array}$ \\
\hline & & & .888 & $\begin{array}{l}\text { V11: Borrowed consumer credit to purchase bed (khat) helps to comfort } \\
\text { sleeping on bed (khat) for family members. }\end{array}$ \\
\hline \multirow[t]{3}{*}{$\mathrm{F} 2$} & \multirow[t]{3}{*}{$\begin{array}{l}\text { Home } \\
(18.24)\end{array}$} & \multirow[t]{3}{*}{2.74} & .875 & $\begin{array}{l}\text { V2: Borrowed consumer credit to purchase TV helps to stay at home for leisure } \\
\text { time and entertainment, thereby avoiding issues such as pollution. }\end{array}$ \\
\hline & & & .866 & $\begin{array}{l}\text { V3: Borrowed consumer credit to purchase household goods helps to perform } \\
\text { household task. }\end{array}$ \\
\hline & & & .839 & $\begin{array}{l}\text { V13: Borrowed consumer credit to purchase TV/ computer/ car/ motorcycle } \\
\text { helps to collect lots of information about home. }\end{array}$ \\
\hline \multirow[t]{3}{*}{ F3 } & \multirow[t]{3}{*}{$\begin{array}{l}\text { Recreation } \\
(11.79)\end{array}$} & \multirow[t]{3}{*}{1.77} & .861 & $\begin{array}{l}\text { v4: Borrowed consumer credit to purchase car/ motorcycle helps to maintain } \\
\text { community. }\end{array}$ \\
\hline & & & .809 & $\begin{array}{l}\text { V6: Borrowed consumer credit to purchase car/ motorcycle helps the family } \\
\text { members to visit enjoyable places for recreation. }\end{array}$ \\
\hline & & & .789 & $\begin{array}{l}\text { V8: Borrowed consumer credit to purchase household goods helps people to } \\
\text { reduce emotion, worries, problem, and tiredness. }\end{array}$ \\
\hline \multirow[t]{2}{*}{ F4 } & \multirow[t]{2}{*}{$\begin{array}{l}\text { Food } \\
(10.01)\end{array}$} & \multirow[t]{2}{*}{1.50} & .877 & $\begin{array}{l}\text { V15: Borrowed consumer credit to purchase blender machine/ oven/ pressure } \\
\text { cooker helps people to enjoy fast food, drink juice \& other tasty food. }\end{array}$ \\
\hline & & & .896 & $\begin{array}{l}\text { V1: Borrowed consumer credit to purchase fridge helps to keep food, fruits, } \\
\text { vegetables etc. fresh. }\end{array}$ \\
\hline \multirow[t]{2}{*}{ F5 } & \multirow[t]{2}{*}{$\begin{array}{l}\text { Fashion } \\
(9.25)\end{array}$} & \multirow[t]{2}{*}{1.39} & .876 & $\begin{array}{l}\text { V12: Borrowed consumer credit to purchase TV/ computer helps to find out } \\
\text { latest fashion. }\end{array}$ \\
\hline & & & .891 & $\begin{array}{l}\text { V14: Borrowed consumer credit to purchase household goods helps to decorate } \\
\text { the home in a new style. }\end{array}$ \\
\hline
\end{tabular}




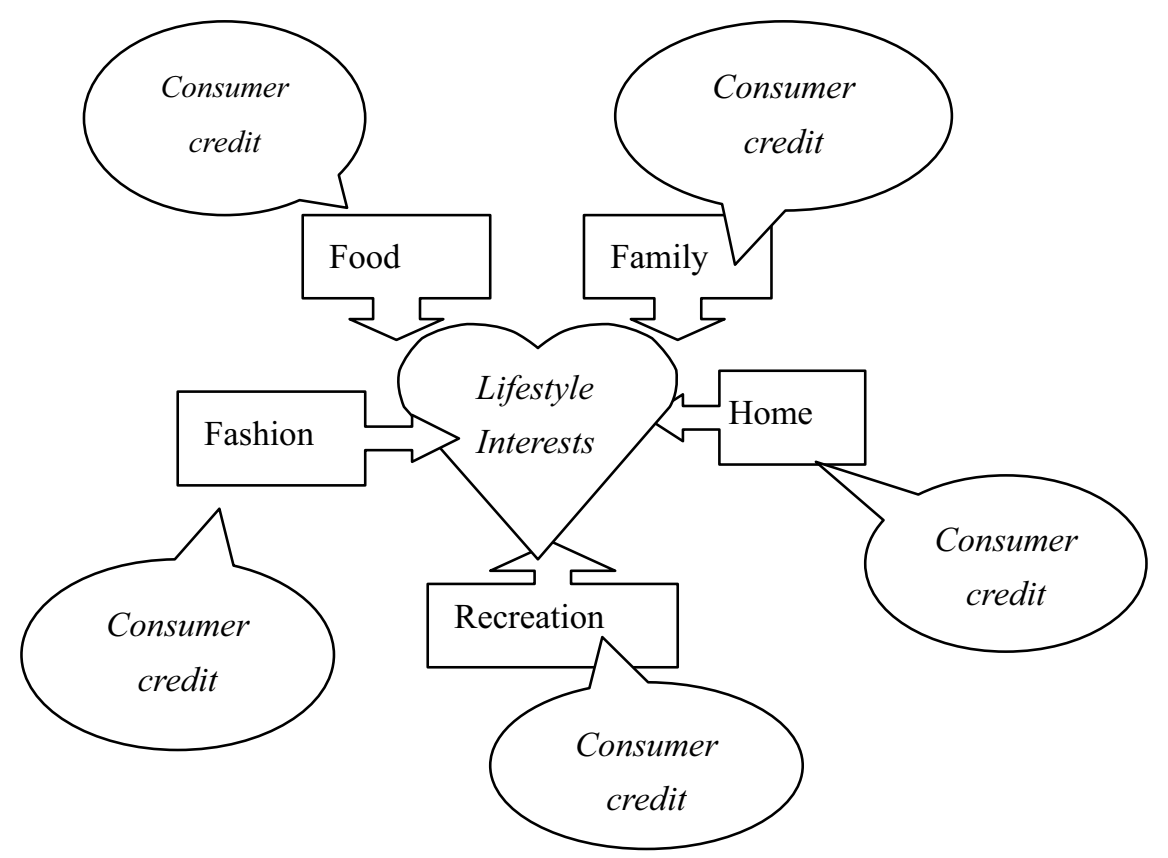

Figure 1. The conceptual model of consumer credit impacts on lifestyle interests of consumers.

\section{Scree Plot}

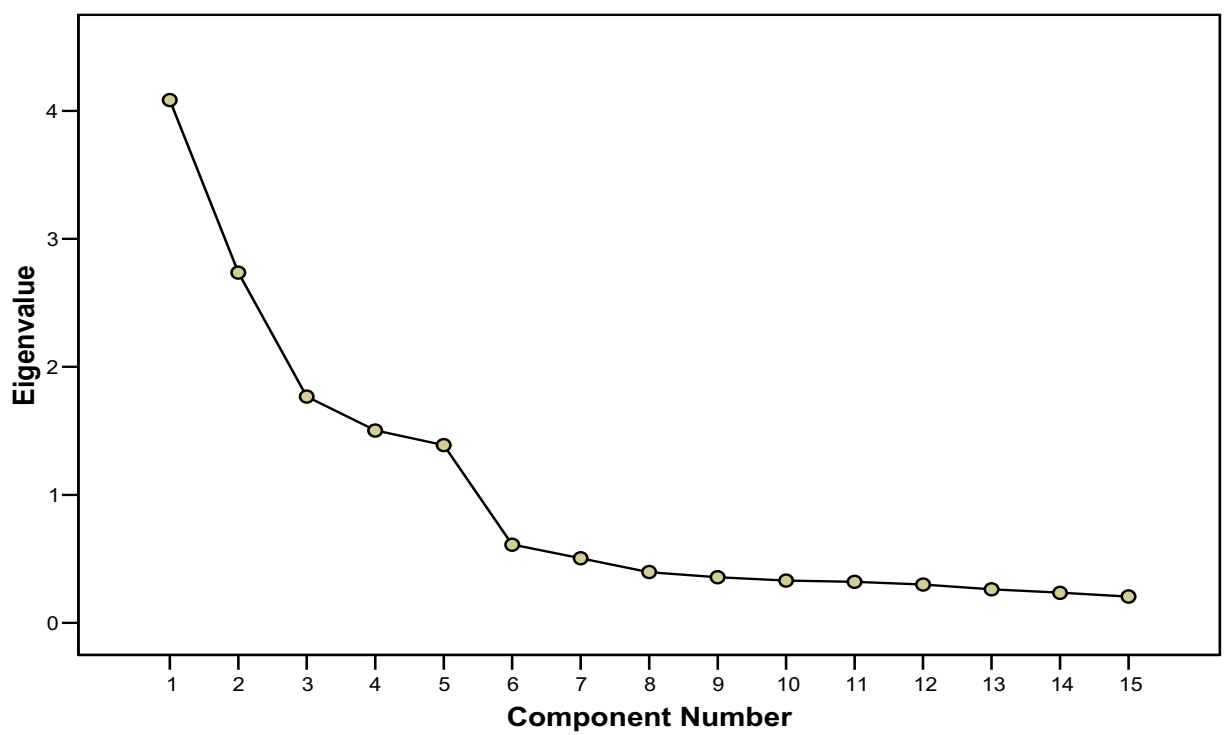

Figure 2. Scree plot of some lifestyle (interests) variables related to consumer credit. 